\title{
Effects of Foreign Direct Investment and Quality of Informal Institution on the Size of the Shadow Economy: Application to Vietnam
}

\author{
Bui Hoang NGOC ${ }^{1}$
}

Received: February 21, 2020 Revised: March 01, 2020 Accepted: March 31, 2020

\begin{abstract}
Tax is the main revenue of Government, so fighting tax evasion and sustainable growth have been the primary macroeconomic goals being pursued by every developing country, Vietnam included. The existence and development of the shadow economic sector are synonymous with the national budget losing out. In Vietnam, foreign direct investment projects do not promote economic growth and is also a sector that gives way to tax evasion. The purpose of this study is to investigate the impact of foreign direct investment, the quality of the informal institution on the size of the shadow economy in Vietnam, during the period 1991-2015. By applying the Autoregressive Distributed Lag approach and Toda and Yamamoto test, we found evidence to conclude that the quality of the informal institution harms the size of the shadow economy. The results of the causality test show that there is a unidirectional causality running from the shadow economy and the quality of the informal institution to foreign direct investment attraction in Vietnam. Political solutions need to be implemented carefully to counter the harmful effects of the shadow economy. Policymakers should adopt several economic policies to improve the 'human capital' and drive the shadow economy into the formal economy.
\end{abstract}

Keyword: Shadow Economy, Quality of Institution, ARDL, Vietnam

JEL Classification Code: O31, O32, D78, Q47, Q53.

\section{Introduction}

The quality of the institution plays an essential role in development and economic growth (North, 1990). The difference in the institutional quality is the fundamental cause of economic growth, to form the developed, developing, and less-developed countries in the long-run (Acemoglu \& Robinson, 2010). Compared to developed countries, the quality of institutions in developing countries has many defects and limitations. It is the cause of the shadow economy sector in developing countries that have always existed. The development of the shadow economy indicates that the formal economy was improving slowly, and the national budget lose out. Besides, it distorts the allocation of

\footnotetext{
${ }^{1}$ First Author and Corresponding Author. Graduate School, Ho Chi Minh City Open University, Vietnam [Postal Address: No. 97, Vo Van Tan Street, Ward 6, District 3, Ho Chi Minh City, 724000, Vietnam] Email: ngocbh.16ae@ou.edu.vn

(c) Copyright: The Author(s)

This is an Open Access article distributed under the terms of the Creative Commons Attribution Non-Commercial License (http://Creativecommons.org/licenses/by-nc/4.0/) which permits unrestricted noncommercial use, distribution, and reproduction in any medium, provided the original work is properly cited.
}

resources, alters income distribution, and reduces revenues through the Government's tax (Alm \& Embaye, 2013). If we ignore this sector, to evaluate the consequences of various economic policies is a futile exercise. The IMF report shows that the size of the Vietnamese shadow economy sector is still equal to $11.18 \%$ of the GDP in 2015 .

The relationship between institutional quality, foreign direct investment and the size of the shadow economy sector is an attractive topic (Larrain \& Tavares, 2004; Kwok \& Tadesse, 2006; Dang, 2013; Dreher \& Schneider, 2010; Razmi, Falahi, \& Montazeri, 2013), but there is a dearth of studies in Vietnam. According to North (1990), the institution is divided into two types: (1) the formal institution (representing the Government effectiveness, regulatory quality, the rule of law, and control of corruption), and (2) the informal institution (culture, religion, the consciousness of ethics, 'human capital' per person). Previous studies often emphasize the role of formal institution quality to reduce the shadow economy. However, Johnson, Kaufmann, and ZoidoLobaton (1998) suggest that the restrictions of the shadow economy by the formal institution will not be valid. The weak skill worker must usually participate in the shadow economy sector due to the fact that the opportunity to participate in 
the formal economy is rstricted. Even if the skill/education of workers is improved, there is still the likelihood that they enter the shadow economy due to fast and straightforward procedures (Schneider, 2012). The purpose of this study is to investigate the effects of FDI and the informal institution quality (measured by the index of the 'human capital' per person) on the size of the shadow economy in Vietnam. Because of the curtailment of the shadow economy by the formal institution as well as the informal institution is the right choice and effectiveness in the long run (Acemoglu \& Robinson, 2013).

\section{Theoretical Background and Literature Review}

The 'shadow economy' labeled by Frey, Weck, and Pommerehne (1982) and Schneider and Dominik (2000) is an associated part of the official economy. It is also known as the irregular economy (Ferman \& Ferman, 1973; Feige, 1979), the parallel economy (Contini, 1981), the black economy (Dilnot \& Morris, 1981), the underground economy (Simon \& Witte, 1982; Feige, 1989), the informal economy (Smith, 1985), and the unofficial economy (Johnson et al., 1998). There is not an adequate and coherent definition of the shadow economy in the literature. Smith (1985) defines the shadow economy as "market-based production of goods and services, whether legal or illegal, that escapes detection in the official estimates of gross domestic products (GDP)". In other words, the shadow economy includes those economic activities and incomes derived from them that avoid Government regulations, taxation, or observation (Feige, 1989; Dell'Anno \& Schneider, 2003). Dell'Anno (2007) regards the shadow economy as a "non-observed economy" which comprises all product activities that can be categorized into three areas: underground production, informal production, and illegal production.

Despite adopting inconsistent definitions of the shadow economy, researchers have generally concurred on a typical aspect of the shadow economy: the area covering economic activities that are not recorded in the national accounts. Schneider (2010) defines the shadow economy to include all production activities of goods and services based on market, but deliberately hidden from public authorities for avoiding income payment, tax payment, payment for social security contributions; they also avoid "having to meet legal labor market standards", such as maximum working hours, minimum wages, safety standards, etc.; they avoid as well "complying with certain administrative procedures" such as completing administrative forms or statistical questionnaires.

According to Hirschman (1970), the proliferation of shadow economic activities is considered the response of people to the overload of the tax burden, social security, and the lack of flexibility of the institution. Instead of voicing their demand for changes to Government and policymakers, people have often chosen a 'safer' way to participate in the shadow economy. It implies that the size of the shadow economy is one of the measurement criteria. It reflects the national institution's quality. Empirical studies show that there are six leading causes to the existence and development of the shadow economic activities: (1) Burdens of taxes and social security contributions (Loayza, 1997; Torgler \& Schneider, 2009; Schneider, 2010); (2) Intensity of Regulations (Loayza, 1997; Johnson et al. 1998; Friedman, Johnson, Kaufmann, \& Zoido-Labton, 2000; Schneider, Buehn, \& Montenegro, 2010); (3) Corruption (Hindriks, Muthoo, \& Keen, 1999; Dreher \& Schneider, 2010); (4) Changes from the labor market (Boeri \& Garibaldi, 2002; Dell'Anno, 2007); (5) Institutional quality/public sector services (Johnson et al., 1998; Friedman et al., 2000; Fugazza \& Jacques, 2003; Torgler \& Schneider, 2009; Dreher, Kotsogiannis, \& McCorriston, 2009; Dreher \& Schneider, 2010; Razmi et al., 2013); and (6) Development of the formal economy (La Porta \& Shleifer, 2014; Williams, 2008; Elgin \& Oztunali, 2014).

\subsection{The Effect of Institutional Quality on the Shadow Economy}

According to Tanzi (1982), Schneider (1997), and Maloney (2004), the existence of the shadow economic activities is the result of low institutional quality. Most of the studies conclude that there is a negative effect of institutional quality on the shadow economy. For example, based on data collected from OECD, Latin America, and transition countries, Johnson et al. (1998) reveal that more corruption and the weak rule of law are causes for a broader shadow economy. The lax regulations without adequate supervision will encourage corruption, leading to more enterprises operating in the shadow economy. Similarly, Friedman et al. (2000), and Torgler and Schneider (2009) also find that improving institutional quality (especially the security of property rights) and higher tax morale can lessen the incentive to 'go underground' and reduce the size of the shadow economy. A higher institution quality leads to a smaller shadow economy and reduces corruption (Dreher et al., 2009). For their part, Fugazza and Jacques (2003) conclude that labor market regulations and tax burden are the reasons for informal economic activities. They support the view that policies should aim at promoting the individual benefits of participating in the formal sector rather than conducting a deterrence policy, because the intervention of Government to labor market will affect both the formal economy and the shadow economy.

Elgin and Oztunali (2014) found that institutional quality drastically interacts with the relationship between economic growth and the shadow economy for 141 countries over the 
period from 1984 to 2009. Notably, a higher level of GDP per capita is related to a larger shadow economy size in the case of low institutional quality, and a smaller shadow economy size in the case of high institutional quality. This result emphasized the critical role of institutional quality in determining whether the shadow economy and the formal economy are substitutes or complement. Furthermore, without the improvement in institutional quality, the growth of the formal economy can reduce the shadow economy, and vice versa

\subsection{The Relationship between FDI and the Shad- ow Economy}

Hypothetically, FDI can help reduce the size of shadow economies through three channels. First, FDI helps improve institutional quality (Larrain \& Tavares, 2004; Kwok \& Tadesse, 2006; Dang, 2013; Long, Ngoc, \& My, 2018), and better institutional quality, in turn, reduces shadow economy (Johnson et al., 1998; Friedman et al., 2000; Fugazza \& Jacques, 2003; Torgler \& Schneider, 2009; Dreher et al., 2009; Dreher \& Schneider, 2010; Razmi et al., 2013). Second, FDI has a positive effect on the growth of the formal economy (Romer, 1994; Choe, 2003; Li \& Liu, 2005; Long et al., 2018; Mustafa, 2019; Nantharath \& Kang, 2019), so that it reduces the size of the shadow economy (La Porta \& Shleifer, 2014; Williams, 2008). Third, FDI creates employment (Lall, 1995; Blomström, Fors, \& Lipsey, 1997), raises wages (Heyman, Sjholm, \& Tingvall, 2007), and improves labor productivity (Le, Duy, \& Ngoc, 2019), thus reducing the size of the shadow economy (Boeri \& Garibaldi, 2002; Dell'Anno \& Solomon, 2008).

Nikopour, Habibullah, Schneider, and Law (2009) used the data of 145 countries from 2000-2005; by applying the Generalized Method of Moments (GMM) approach, they conclude that there is bi-directional causality between FDI and the shadow economy. Accordingly, the increase in FDI will boost the shadow economic activities, and the size of the shadow economy sector increased to attract better FDI. Similarly, Ali and Bohara (2017) confirm that a higher shadow economy increases FDI inflows since multienterprises take advantage of tax evasion in host countries with the larger size of the shadow economy. However, Davidescu and Strat (2015) find a negative impact of FDI on the shadow economy in the short run in the case of Romania.

\section{Data and Methodology}

\subsection{Research Model}

In literature, shadow economic activity also created material wealth for society, but for various reasons are not counted in formal GDP. The size of the shadow economy sector is calculated based on formal GDP. This study is based on the previous research of Dell'Anno and Schneider (2003), Nikopour et al. (2009), to determine the relationship between foreign direct investment, informal institutional quality and the size of the shadow economy sector in Vietna. we suggest the following research model:

$$
S E_{t}=\beta_{0}+\beta_{1} \cdot \operatorname{Ln}(F \mathrm{D} I)_{t}+\beta_{2} \cdot H C_{t}+u_{t}
$$

The annual data are collected from 1991 to 2015. Where the 'SE' variable is the percentage of the shadow economy as compared to GDP (source: IMF). 'LnFDI' variable is the logarithm of total FDI (source: UNCTAD) and the 'HC' variable is the informal institution quality (measured by the index of human capital per person) (source: FRED).

\subsection{Method}

According to Nelson and Plosser (1982), Omri, Nguyen, and Rault (2014), GDP or FDI is a persistent time series data. It implies that there is a relationship between the current GDP/FDI with the previous GDP/FDI. To solve this problem, we employed the Autoregressive Distributed Lags (ARDL) approach proposed by Pesaran, Shin, and Smith (2001). Eq.1 are illustrated in the following ARDL model:

$$
\begin{aligned}
& \Delta S E_{t}=\beta_{0}+\beta_{1} \cdot S E_{t-1}+\beta_{2} \cdot L n F \mathrm{DI} I_{t-1}+\beta_{3} \cdot H C_{t-1} \\
& +\sum_{i=1}^{m 1} \beta_{4 i} \cdot \Delta S E_{t-i}+\sum_{i=0}^{m 2} \beta_{5 i} \cdot \Delta L n F \mathrm{DI} I_{t-i}+\sum_{i=0}^{m 3} \beta_{6 i} \cdot \Delta H C_{t-i}+\mu_{t}
\end{aligned}
$$

Note: $\Delta$ denotes the first difference

$\beta_{1}, \beta_{2}, \beta_{3}$ are regression coefficients that present long-term effects

$\beta_{4}, \beta_{5}, \beta_{6}$ are regression coefficients that present short-term effects

$\mu_{t}$ is error

According to Pesaran et al. (2001), the variables in the ARDL model must satisfy two conditions: (1) The variables are stationary; (2) There is cointegration among variables. If there is a cointegration relationship in the long-run, Eq.2 was estimated based on the Error Correction Model (ECM), as follows:

$$
\begin{aligned}
& \Delta S E_{t}=\beta_{0}+\alpha \cdot E C M_{t-1} \\
& +\sum_{i=1}^{m 1} \lambda_{i i} \cdot \Delta S E_{t-i}+\sum_{i=0}^{m 2} \lambda_{2 i} \cdot \Delta L n F \mathrm{D} I_{t-i}+\sum_{i=0}^{m 3} \lambda_{3 i} \cdot H C_{t-i}+\tau_{t}
\end{aligned}
$$


Where: $\mathrm{m}_{1}, \mathrm{~m}_{2}, \mathrm{~m}_{3}$ is the lag of each variable is calculated according to AIC, SC, HQ critical information value, and R-square. To determine the causality between SE, LnFDI and $\mathrm{HC}$ variable we employed the modified Wald test, proposed by Toda and Yamamoto (1995). The Toda and Yamamoto procedure examines the levels of the variables based on the Vector Autoregressive model (VAR). For the three variables SE, LnFDI and HC, the VAR model is given as:

$$
\begin{aligned}
& S E_{t}=\alpha_{0}+\sum_{i=1}^{k} \alpha_{1 i} S E_{t-i}+\sum_{j=k+1}^{h} \alpha_{21} S E_{t-j}+\sum_{i=1}^{k} \delta_{1 i} L n F \mathrm{D} I_{t-i} \\
& +\sum_{j=k+1}^{h} \delta_{2 i} L n F \mathrm{D} I_{t-j}+\sum_{i=1}^{k} \theta_{1 i} H C_{t-i}+\sum_{j=k+1}^{h} \theta_{2 i} H C_{t-j}+\mu_{1 t} \\
& L n F \mathrm{D} I_{t}=\beta_{0}+\sum_{i=1}^{k} \beta_{1 i} L n F \mathrm{D} I_{t-i}+\sum_{j=k+1}^{h} \beta_{2 i} L n F \mathrm{D} I_{t-j} \\
& +\sum_{i=1}^{k} \theta_{1 i} H C_{t-i}+\sum_{j=k+1}^{h} \theta_{2 i} H C_{t-j}+\sum_{i=1}^{k} \alpha_{1 i} S E_{t-i}+\sum_{j=k+1}^{h} \alpha_{2 i} S E_{t-j} \\
& +\mu_{2 t} \\
& H C_{t}=\gamma_{0}+\sum_{i=1}^{k} \gamma_{1 i} H C_{t-i}+\sum_{j=k+1}^{h} \gamma_{2 i} H C_{t-j}+\sum_{i=1}^{k} \alpha_{1 i} S E_{t-i}+ \\
& \sum_{j=k+1}^{h} \alpha_{2 i} S E_{t-j}+\sum_{i=1}^{k} \delta_{1 i} L n F \mathrm{D} I_{t-i}+\sum_{j=k+1}^{h} \delta_{2 i} L n F \mathrm{D} I_{t-j}+\mu_{3 t}
\end{aligned}
$$

where: $\mathrm{k}$ is the lag length of the VAR model, which is chosen following AIC, SC, HQ criteria information value, and $\mathrm{h}=\left(\mathrm{k}+\mathrm{d}_{\max }\right)$, with $\mathrm{d}_{\max }$ is the maximum lag length, obtained from the results of stationarity test. According to Toda and Yamamoto (1995), the maximum of $d_{\max }$ is 2 , because if $d_{\max }>$ 2 the tests based on F-statistic are not reliable (Nkoro \& Uko, 2006). In Eq.4, Eq.5, Eq.6, LnFDI has a causal effect on SE if $\exists \delta_{1 \mathrm{i}} \neq 0 \quad \forall$ i; HC has a causal effect on LnFDI if $\exists \theta_{1 \mathrm{i}} \neq 0 \quad \forall$; and SE has a causal effect on $\mathrm{HC}$ if $\exists \alpha_{1 \mathrm{i}} \neq 0 \quad \forall$. The Granger classical causality test is based on variables with stationary at I(1). Toda and Yamamoto (1995) test can be applied whether the variable is stationary at $\mathrm{I}(0)$ or $\mathrm{I}(1)$, and there exists cointegration or no-cointegration (Mavrotas \& Kelly, 2001).

\section{Empirical Results and Discussion}

\subsection{Descriptive Statistics}

The IMF report shows that the size of the shadow economy in Vietnam has continually decreased from 1991 to the present. In 2015, the size of the shadow economic activities in Vietnam was $14.78 \%$, lower than the $27.78 \%$ on average of 158 countries. In 2015, the size of the shadow economy sector of Thailand was $43.12 \%$, Singapore $9.2 \%$, Philippines $28.04 \%$, Myanmar 50.99\%, Malaysia 26.07\%, Laos 25\%, Indonesia $21.76 \%$, and Cambodia $33.85 \%$. That means the current size of the shadow economy of Vietnam is only higher than that of Singapore and is lower than that of most other Asian countries. Meanwhile, attracting FDI and the 'human capital' of Vietnam keeps improving. In 2015, Vietnam attracted 11.8 billion in FDI coming from 126 countries and territories with investment activities in Vietnam. Descriptive statistics of the variables are shown in Table 1.

Table 1: Descriptive statistics of the variables

\begin{tabular}{|l|c|c|c|}
\hline & SE & LnFDI & HC \\
\hline Mean & 15.0948 & 7.8893 & 2.1355 \\
\hline Median & 15.3200 & 7.5776 & 2.0977 \\
\hline Maximum & 18.6400 & 9.3758 & 2.6700 \\
\hline Minimum & 11.1800 & 5.9274 & 1.7219 \\
\hline Std. Deviation & 2.31353 & 0.9899 & 0.3008 \\
\hline Skewness & -0.03663 & -0.0349 & 0.2919 \\
\hline Kurtoris & 1.78405 & 2.0132 & 1.8034 \\
\hline Jarque-Bera & 1.78405 & 1.0195 & 1.8467 \\
\hline Probability & 0.46169 & 0.6007 & 0.3972 \\
\hline
\end{tabular}

\subsection{Empirical Results}

\subsubsection{Unit-root Test}

While using time series data, the first step is to examine the stationarity of all the variables. We use both the Augmented Dickey-Fuller (1981) (ADF test) and Phillips and Perron (1988) (PP test) to test the tendency of a unit-root test over a time series. With the null hypothesis $\left(\mathrm{H}_{0}\right.$ : Data is not stationary) against the alternative hypothesis $\left(\mathrm{H}_{1}\right.$ : Data is stationary). The results of the unit-root test of variables are shown in Table 2. Results in Table 2 shown SE, HC variables were stationary at I(0), LnFDI variable was stationary at I(1). So, the conditions to apply the ARDL model, Toda and Yamamoto test $(\operatorname{dmax}<2)$ are satisfied.

Table 2: Results of the stationary test

\begin{tabular}{|l|l|l|l|l|}
\hline \multirow{2}{*}{ Variable } & \multicolumn{2}{|c|}{ Level } & \multicolumn{2}{c|}{ First difference } \\
\cline { 2 - 5 } & ADF test & PP test & ADF test & PP test \\
\hline SE & $-4.555^{* * *}$ & $-4.556^{* * *}$ & $-7.551^{* * *}$ & $-11.073^{\star * *}$ \\
\hline LnFDI & -1.402 & -1.450 & $-3.278^{* *}$ & $-3.236^{* *}$ \\
\hline HC & -3.106 & $-3.601^{*}$ & -3.368 & $-3.867^{*}$ \\
\hline
\end{tabular}

${ }^{* * *},{ }^{* *}$ and * respectively denote significance levels of $1 \% ; 5 \%$ and $10 \%$. 


\subsubsection{Determination of Optimal Lag Length}

In the ARDL model, identification of optimal lag length is important. The optimal lag length indicates the volatility of the variables in the current period is in correlation with how many the previous period. Based on $\mathrm{AIC}, \mathrm{SC}, \mathrm{HQ}$ critical information, the length of optimal lags of Vietnam's data is 2 and the optimal model for Eq. 2 is $\operatorname{ARDL}(1,1,0)$. Then, in Eq. $2, \mathrm{~m}_{1}=\mathrm{m}_{2}=1$, and $\mathrm{m}_{3}=0$.

\subsubsection{Cointegration Test}

This study employed Bounds testing to check the cointegration among variables. The Bounds testing is based on the F-statistics. The null hypothesis in Eq.2 is $\left(\mathrm{H}_{0}\right.$ : $\left.\beta_{1}=\beta_{2}=\beta_{3}=0\right)$ against the alternative hypothesis $\left(\mathrm{H}_{1}\right.$ : $\left.\beta_{1} \neq \beta_{2} \neq \beta_{3} \neq 0\right)$. According to Pesaran et al. (2001), if $\mathrm{F}$ value lies below the $\mathrm{F}$ critical values (the lower bound value, $\mathrm{I}(0))$, it is the indication toward the acceptance of the null hypothesis. That means there is no cointegration among variables. While the $\mathrm{F}$ value exceeds the $\mathrm{F}$ critical value (the upper bound value, I(1)), we will reject the null hypothesis. The result of the Bounds testing was shown in Table 3. The F value in Table $3(=6.5607)$ is higher than the critical value of the upper bound $(=5)$ at the significance level of $1 \%$. So, it is clear evidence to conclude that long-run relationship exists among SE, LnFDI, and HC variable.

Table 3: Result of the Bounds testing

\begin{tabular}{|c|c|c|c|c|}
\hline \multicolumn{2}{|c|}{ F-Bounds test } & \multicolumn{3}{c|}{ Null hypothesis: No } \\
cointegration among variables
\end{tabular}

\subsubsection{Results of the Short-Term and Long-Term Estimation}

After examining the long-run relationship between the variables, we employed the Error Correction Model (ECM) to determine the short-run and long-run coefficients. The coefficient of ECM(-1) is -0.8687 , which is significant at $1 \%$. It implies that the shadow economy was able to adjust to longrun equilibrium after each short-run 'shock.' The attraction of FDI has a positive, but no significant, effect on the shadow economy. There is no relationship between the informal institution quality and shadow economy in the short run.
The result of long-run effect is shown in Table 4. The coefficient of the ' $\mathrm{HC}$ ' variable is significant, while the LnFDI variable is not significant. Accordingly, the impact of the informal institution quality on the size of the shadow economy is negative. A one-point increase in the quality of the informal institution will reduce the size of the shadow economy by $8,6 \%$ in Vietnam. The diagnostic tests are detailed in Table 4 in the lower segment. The results suggest that the Eq.2 model seems to pass heteroskedasticity, autocorrelation, and the distribution of residual test. It indicates that there is no problem with autocorrelation and heteroskedasticity. Hence, the conditions of the ARDL model in Eq. 2 were satisfied.

Table 4: Short-run and long-run estimation

\begin{tabular}{|c|c|c|c|}
\hline \multicolumn{4}{|c|}{ Dependent variable: SE } \\
\hline Variables & Coefficient & T-statistic & Probability \\
\hline \multicolumn{4}{|l|}{$\begin{array}{l}\text { Short-run } \\
\text { results }\end{array}$} \\
\hline Constant & $26.2448^{* * *}$ & 3.8288 & 0.0011 \\
\hline$\Delta \mathrm{LnFDI}$ & 0.2082 & 0.7689 & 0.4514 \\
\hline $\mathrm{ECM}(-1)$ & $-0.8687^{* * *}$ & -5.5124 & 0.0000 \\
\hline Adj-R ${ }^{2}$ & 0.4347 & & \\
\hline \multicolumn{4}{|l|}{$\begin{array}{l}\text { Long-run } \\
\text { results }\end{array}$} \\
\hline Constant & $30.2109^{* * *}$ & 31.2009 & 0.0000 \\
\hline LnFDI & 0.4061 & 1.5179 & 0.1455 \\
\hline $\mathrm{HC}$ & $-8.6048^{* * *}$ & -10.2342 & 0.0000 \\
\hline Adj-R ${ }^{2}$ & 0.9583 & & \\
\hline F-statistic & $133.2215^{\star * *}$ & & \\
\hline \multicolumn{4}{|l|}{$\begin{array}{l}\text { Diagnostic } \\
\text { tests }\end{array}$} \\
\hline \multicolumn{2}{|c|}{ Test } & F-statistic & Probability \\
\hline \multicolumn{2}{|c|}{$\begin{array}{l}\text { Test of Heteroskedasticity } \\
\text { (White test) }\end{array}$} & 0.8546 & 0.5085 \\
\hline \multicolumn{2}{|c|}{$\begin{array}{l}\text { Test of Serial correlation } \\
\text { (Breusch-Godfrey test) }\end{array}$} & 0.0015 & 0.9986 \\
\hline \multicolumn{2}{|c|}{$\begin{array}{l}\text { Test of Histogram } \\
\text { (Normality test) }\end{array}$} & 0.0798 & 0.9608 \\
\hline \multicolumn{2}{|c|}{$\begin{array}{l}\text { Test of the suitable model } \\
\text { (Ramsey-Reset test) }\end{array}$} & 3.2621 & 0.0876 \\
\hline
\end{tabular}

\subsubsection{Stability Tests}

Next, we employed the Cumulative Sum of Recursive Residuals (CUSUM), and the Cumulative Sum of Squares of Recursive Residuals (CUSUMSQ) tests to check the 
stability of the ARDL model. The results of the CUSUM and CUSUMSQ are shown in Figure 1a and Figure $1 \mathrm{~b}$. These figures indicate the stability of the ARDL parameters because graphs of both tests are lying within critical Bounds at $5 \%$ level of significance. So, we can say that our model is stable, and the coefficients of estimation are reliable for forecasts or policy-making.

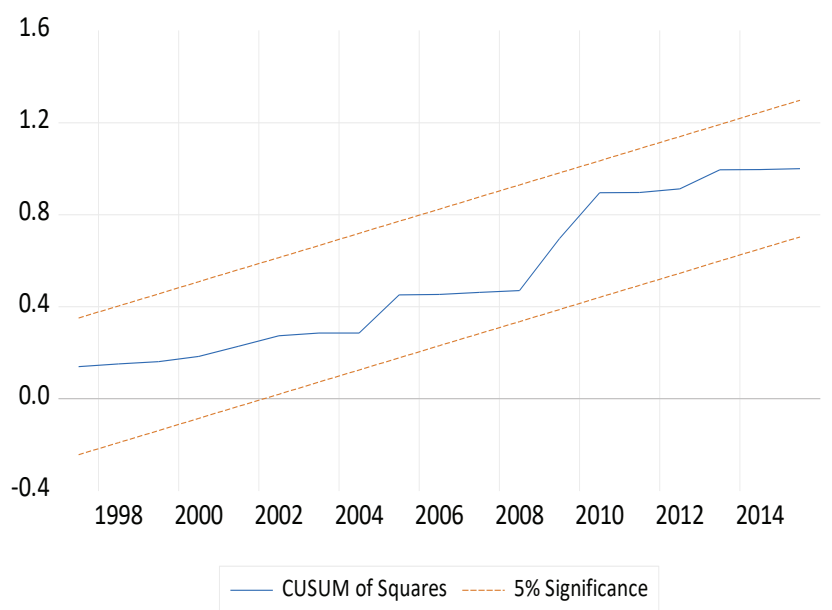

Figure 1a: Result of the CUSUM test

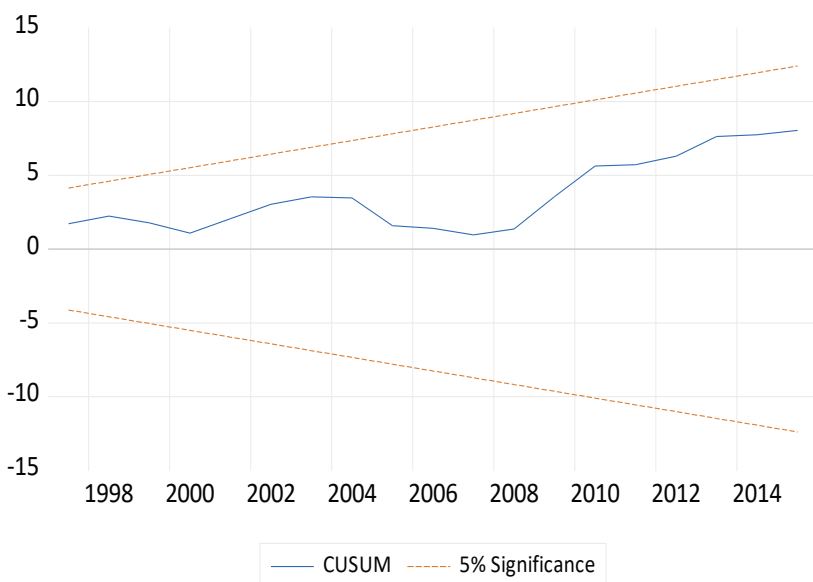

Figure 1b: Result of the CUSUMSQ test

\subsubsection{Causality Test}

Finally, to determine the causality between the variables, the Toda and Yamamoto (1995) test were applied. The null hypothesis is $\left(\mathrm{H}_{0}\right.$ : There is not cause) against the alternative hypothesis $\left(\mathrm{H}_{1}\right.$ : there is the cause). Outcomes of the causality tests confirm that there is a unidirectional causality running from the shadow economy to FDI, from HC to FDI. There is no evidence to conclude that foreign direct investment and the quality of the informal institution have a causal relationship with the shadow economy (see Table 5).
Table 5: Results of the causality tests

\begin{tabular}{|l|c|c|}
\hline \multicolumn{1}{|c|}{ Null hypothesis: No causality } & F-Statistic & Prob \\
\hline LnFDI does not Granger cause SE & 0.62831 & 0.5448 \\
\hline SE does not Granger cause LnFDI & 4.20484 & 0.0317 \\
\hline HC does not Granger cause SE & 2.72397 & 0.0926 \\
\hline SE does not Granger cause HC & 0.68636 & 0.5161 \\
\hline HC does not Granger cause LnFDI & 4.42136 & 0.0274 \\
\hline LnFDI does not Granger cause HC & 0.44396 & 0.6483 \\
\hline
\end{tabular}

\section{Conclusions and Policy Implications}

This study investigates the impact of foreign direct investment and the quality of the informal institution on the size of the shadow economy sector in the case of Vietnam. We applied the ARDL approach for short-run and long-run cointegration dynamics, which cover the period from 1991 to 2015. We also employed some diagnostic tests, and stability tests show that the model is stable. Empirical findings of this study suggest some conclusions as follows:

- The quality of the informal institution harms the size of the shadow economy. There is no statistical evidence to conclude that foreign direct investment has an impact on the shadow economic activities in Vietnam.

- There is a unidirectional causality running from the shadow economy and informal institution quality to foreign direct investment attraction in the case of Vietnam.

From the empirical results, the author suggests that the Government should implement a plan to improve institutional quality. Policies for institutional reform and reduction of shadow economy should be simultaneously carried out to intensify the effectiveness of the combination.

\section{References}

Acemoglu, D., \& Robinson, J. A. (2010). The role of institutions in growth and development. Review of Economics and Institutions, 1(2), 1-33.

Acemoglu, D., \& Robinson, J. A. (2013). Why nations fail: the origins of power, prosperity and poverty. Journal of Organizational Change Management, 32(1), 154-156.

Ali, M., \& Bohara, A. (2017). How Does FDI Respond to the Size of Shadow Economy: An Empirical Analysis under a Gravity Model Setting. International Economic Journal, 31(2), 159178.

Alm, J., \& Embaye, A. (2013). Using Dynamic Panel Methods to Estimate Shadow Economies Around the World, 1984-2006. Public Finance Review, 41(5), 510-543.

Blomström, M., Fors, G., \& Lipsey, R. E. (1997). Foreign Direct Investment and Employment: Home Country Experience in the 
United States and Sweden. The Economic Journal, 107, 17871797.

Boeri, T., \& Garibaldi, P. (2002). Shadow activity and unemployment in a depressed labor market (CEPR Discussion Papers 3433).

Choe, J. (2003). Do Foreign Direct Investment and Gross Domestic Investment Promote Economic Growth? Review of Development Economics, 7(1), 44-57.

Contini, B. (1981). Labor Market Segmentation and the Development of the Parallel Economy - The Italian Experience. Oxford Economic Papers, 33(4), 401-412.

Dang, D. (2013). How foreign direct investment promote institutional quality: Evidence from Vietnam. Journal of Comparative Economics, 41(4), 1054-1072.

Davidescu, A.A., \& Strat, V.A. (2015). Shadow Economy And Foreign Direct Investments: An Empirical Analysis For The Case Of Romania. Ecoforum, 4(2), 110-118.

Dell'Anno, R., \& Schneider, F. (2003). The Shadow Economy of Italy and Other OECD Countries: What Do We Know? Journal of Public Finance and Public Choice, 21(2-3), 97-120.

Dell'Anno, R., \& Solomon, O. H. (2008). Shadow economy and unemployment rate in the USA: Is there a structural relationship? An empirical analysis. Applied Economics, 40(19), 2537-2555.

Dell'Anno, R. (2007). The Shadow Economy in Portugal: An Analysis with the MIMIC Approach. Journal of Applied Economics, 10(2), 253-277.

Dickey, D.A., \& Fuller, W.A. (1981). Likelihood ratio statistics for autoregressive time series with a unit root. Econometrica, 49, 1057-1072.

Dilnot, A., \& Morris, C. (1981). What do we know about the black economy in the United Kingdom? Fiscal Studies, 2(1), 58-73.

Dreher, A., \& Schneider, F. (2010). Corruption and the shadow economy: An empirical analysis. Public Choice, 144(1), 215-238.

Dreher, A., Kotsogiannis, C., \& McCorriston, S. (2009). How do institutions affect corruption and the shadow economy? International Tax Public Finance, 16, 773-796.

Elgin, C., \& Oztunali, O.(2014). Institutions, Informal Economy and Economic Development. Emerging Markets Finance and Trade, 50(4), 145-162.

Feige, E. L. (1979). How big is the irregular economy? Challenge, 22(1), 5-13.

Feige, E. L. (1989). The Underground Economies. Tax Evasion and Information Distortion. Cambridge, UK: Cambridge University Press.

Ferman, P., \& Ferman, L. (1973). The structural underpinning of the irregular economy. Asia Pacific Journal of Human Resources, 8(1), 1-17.

Frey, B., Weck, H., \& Pommerehne, W. (1982). Has the shadow economy grown in Germany? An exploratory study. Review of World Economics, 118, 499-524.

Friedman, E., Johnson, F., Kaufmann, D., \& Zoido-Labton, P. (2000). Dodging the grabbing hand: The determinants of unofficial activity in 69 countries. Journal of Public Economics, 76(4), 459-493.

Fugazza, M., \& Jacques, J. F. (2003). Labor market institutions, taxation and the underground economy. Journal of Public Economics, 88(1-2), 395-418.

Heyman, F., Sjholm, F., \& Tingvall, P. (2007). Multinationals, cross-border acquisitions and wage dispersion. Canadian Journal of Economics, 44(2), 627-650.

Hindriks, J., Muthoo, A., \& Keen, M. (1999). Corruption, extortion and evasion. Journal of Public Economics, 74(3), 395-430.

Hirschman, A. O. (1970). Exit, Voice and Loyalty. Cambridge, MA: Harvard University Press.

Johnson, S., Kaufmann, D., \& Zoido-Lobaton, P. (1998). Regulatory Discretion and the Unofficial Economy. American Economic Review, 88(2), 387-92.

Kwok, C. C., \& Tadesse, S. (2006). The MNC as an agent of change for host-country institutions: FDI and corruption. Journal of International Business Studies, 37, 767-785.

La Porta, R., \& Shleifer, A. (2014). Informality and development. Journal of Economic Perspectives, 28, 109-126.

Lall, S. (1995). Employment and Foreign Investment: Policy Options for Developing Countries. International Labor Review, 134(4-5), 521-540.

Larrain, F., \& Tavares, J. (2004). Does Foreign Direct Investment Decrease Corruption? Cuadernos de Economia, 41, 217-230.

Le, N. H., Duy, L. V. Q., \& Ngoc, B. H. (2019). Effects of Foreign Direct Investment and Human Capital on Labour Productivity: Evidence from Vietnam. Journal of Asian Finance, Economics and Business, 6(3), 123-130. https://doi.org/10.13106/ jafeb.2019.vol6.no3.123.

Li, X., \& Liu, X. (2005). Foreign direct investment and economic growth: An increasingly endogenous relationship. World Development, 33(3), 393-407.

Loayza, N. V. (1997). The economics of the informal sector: A simple model and some empirical evidence from Latin America. Carnegie-Rochester Conference Series on Public Policy, 45, 129-162.

Long, P.D., Ngoc, B.H., \& My, D.T.H. (2018). The Relationship between Foreign Direct Investment, Electricity Consumption and Economic Growth in Vietnam. International Journal of Energy Economics and Policy, 8(3), 267-274.

Maloney, W. (2004). Informality Revisited. World Development, $32(7), 1159-1178$.

Mavrotas, G., \& Kelly, G. (2001). Old wine in new bottles: Testing causality between savings and growth. Manchester School, 69(1), 97-105.

Mustafa, A.M.M. (2019). Contribution of Tourism and Foreign Direct Investment to Gross Domestic Product: Econometric Analysis in the Case of Sri Lanka. Journal of Asian Finance, Economics and Business, 6(4), 109-114. https://doi. org/10.13106/jafeb.2019.vol6.no4.109. 
Nantharath, P., \& Kang, E. (2019). The Effects of Foreign Direct Investment and Economic Absorptive Capabilities on the Economic Growth of the Lao People's Democratic Republic. Journal of Asian Finance, Economics and Business, 6(3), 151162. https://doi.org/10.13106/jafeb.2019.vol6.no3.151

Nelson, C., \& Plosser, C.(1982). Trends and random walks in macroeconomic time series: Some evidence and implications. Journal of Monetary Economics, 10(2), 139-162.

Nikopour, H., Habibullah, M. S., Schneider, F., \& Law, S. H. (2009). Foreign direct investment and Shadow Economy: A causality analysis using panel data. (Munich Personal RePEc Archive, No.14485). Retrieved from http://mpra.ub.uni-muenchen. de/14485.

Nkoro, E., \& Uko, A. K. (2006). Autoregressive Distributed Lag (ARDL) cointegration technique: Application and Interpretation. Journal of Statistical and Econometric Methods, 5(4), 63-91.

North, D. (1990). Institutions, institutional change, and economic performance. New York, NY: Cambridge University Press.

Omri, A., Nguyen, D.K., \& Rault, C. (2014). Causal interactions between $\mathrm{CO}_{2}$ emissions, FDI, and economic growth: Evidence from dynamic simultaneous-equation models. Economic Modelling, 42, 382-389.

Pesaran, M. H., Shin, Y., \& Smith, R.J. (2001). Bounds testing approaches to the analysis of level relationships. Journal of Applied Econometrics, 16(3), 289-326.

Phillips, P.C.B., \& Perron, P. (1988). Testing for a unit root in time series regression. Biomètrika, 75(2), 335-346.

Razmi, M. J., Falahi, M. A., \& Montazeri, S. (2013). Institutional Quality and Underground Economy of 51 OIC Member Countries. Universal Journal of Management and Social Sciences, 3(2), 1-14.

Romer, P. M. (1994). The Origins of Endogenous Growth. The Journal of Economic Perspectives, 8(1), 3-22.
Schneider, F. (1997). The shadow economies of Western Europe. Journal of Institute of Economic Affairs, 17, 42-48.

Schneider, F. (2010). The Influence of Public Institutions on the Shadow Economy: An Empirical Investigation for OECD Countries. Review of Law \& Economics, 6(3), 441-468.

Schneider, F. (2012). The Shadow Economy and Work in the Shadow: What do we (not) know? (Discussion Paper No. 6423). Forschungsinstitut zur Zukunft der Arbeit Institute for the Study of Labor.

Schneider, F., \& Dominik, H. E. (2000). Shadow Economies: Size, Causes, and Consequences. Journal of Economic Literature, $38,77-114$.

Schneider, F., Buehn, A., \& Montenegro, C. E. (2010). New Estimates for the Shadow Economies all over the World. International Economic Journal, 24(4), 443-461.

Simon, C., \& Witte, A. (1982). Beating the system: The underground economy. Boston, MA: Auburn House Publishing Company.

Smith J.D. (1985). Market Motives in the Informal Economy. In W. Gaertner \& A. Wenig (eds), The Economics of the Shadow Economy (Vol. 15). Berlin, Heidelberg: Springer.

Tanzi, V. (1982). The underground economy in the United States and abroad. Lexington, MA: D.C. Heath.

Toda, H.Y., \& Yamamoto, T. (1995). Statistical inference in vector autoregressive with possibly integrated processes. Journal of Econometrics, 66(1), 225-250.

Torgler, B., \& Schneider, F. (2009). The impact of tax morale and institutional quality on the shadow economy. Journal of Economic Psychology, 30(2), 228-245.

Williams, C. (2008). A critical evaluation of competing representations of the relationship between formal and informal work. Community, Work \& Family, 11(1), 105-124. 